\section{Bone mineral density in HIV-infected women taking antiretroviral therapy: a systematic review}

\author{
Densidade mineral óssea em mulheres infectadas pelo vírus do HIV \\ e tratadas com terapia antirretroviral: uma revisão sistemática
}

Érico Higino de Carvalho', Thais Gelenske', Francisco Bandeira², Maria da Fátima Pessoa Militão de Albuquerque ${ }^{3}$

\title{
SUMMARY
}

There is a high prevalence of osteoporosis in HIV-infected patients. Initially described in HIVpositive men, studies have also demonstrated a high prevalence of osteoporosis in HIV-infected women. It would appear that antiretroviral therapy (ART) plays an important role in the pathogenesis of osteoporosis in HIV-infected patients, although little is known about its importance in relation to osteoporosis and fractures in HIV-positive women. The aim of this systematic review was to evaluate the frequency of bone loss, bone mineral density (BMD) and fractures in HIVpositive women taking ART or protease inhibitors (PI). After screening 597 citations from the databases of PubMed, EMBASE and Lilacs, five studies were selected for the review. A difference was demonstrated of over $3 \%$ in the BMD at the femoral neck of HIV-positive women taking PI/ ART. No difference was registered in the BMD at the lumbar spine between users and non-users of PI/ART. The lack of studies has made it impossible to reach any conclusion regarding the occurrence of fractures. Arq Bras Endocrinol Metab. 2010;54(2):133-42

\section{Keywords}

HIV; osteoporosis; fractures, bone; bone density; highly active antiretroviral therapy; systematic review

\section{SUMÁRIO}

A prevalência de osteoporose é elevada em indivíduos infectados pelo HIV. Inicialmente descrita em homens HIV-positivos, estudos demonstraram alta prevalência de osteoporose também em mulheres HIV-positivas. A terapia antirretroviral parece exercer papel importante na patogênese da osteoporose dos indivíduos com HIV. Pouco se sabe sobre sua importância para a osteoporose e fraturas nas mulheres HIV-positivas. Esta revisão objetivou avaliar a frequência de perda de massa óssea, densidade mineral óssea (DMO) e fraturas em mulheres HIV-positivas em uso de terapia antirretroviral (TARV) ou inibidores de protease (IP). Após busca nos bancos de dados PubMed, EMBASE e Lilacs, de 597 citações, cinco estudos permaneceram na revisão. Demonstrou-se haver uma diferença superior a 3\% na DMO no colo do fêmur de mulheres HIV-positivas em uso de IP/TARV. Não se evidenciou diferença na DMO da coluna lombar entre usuárias e não usuárias de IP/TARV. A escassez de estudos impossibilitou qualquer conclusão sobre a ocorrência de fraturas. Arq Bras Endocrinol Metab. 2010;54(2):133-42

Descritores

HIV; osteoporose; fraturas ósseas; densidade mineral óssea; terapia antirretroviral; revisão sistemática

\section{INTRODUCTION}

$\mathrm{O}$ steoporosis is a disorder characterized by decreased bone density and deterioration of the skeletal microarchitecture, resulting in bone fragility (1).
1 Serviço de Medicina Interna e Endocrinologia Instituto de Medicina Integral Professor Fernando Figueira (IMIP), Recife, PE, Brasil ${ }^{2}$ Departamento de Medicina Interna, Faculdade de Ciências Médicas, Universidade de Pernambuco, Recife, PE, Brasil ${ }^{3}$ Centro de Pesquisa Aggeu Magalhães. Fundação Oswaldo Cruz (Fiocruz), Recife, PE, Brasil
Correspondence to: Érico Higino de Carvalho Rua Caio Pereira, 30/2402 52041- 010 - Recife, PE, Brasil ericohc@hotmail.com

Received on Dec/10/2009 Accepted on Feb/19/2010 criteria osteoporosis is defined as a bone mineral density T-score $<-2.5$ and osteopenia between -1 and -2.5 SD (2). The importance of diagnosing osteoporosis and 
osteopenia by DXA is based on the fact that the risk of fracture doubles at each SD below normal in the healthy population (3).

It has been demonstrated that in HIV-infected individuals the prevalence of osteoporosis is up to three times higher than in sero-negative individuals (4). Initially described in HIV-positive men $(5,6)$, recent studies have also shown a high prevalence of osteoporosis in HIV-infected women (7).

The pathogenesis of osteoporosis in HIV-infected individuals has not been completely elucidated. It is known that traditional risk factors, such as hypogonadism, low body weight, smoking, alcohol and drug abuse, are more frequent in the HIV-positive population $(8,9)$. It would also seem that other factors associated to HIV infection are linked to these traditional risk factors. Studies have demonstrated that individuals with low nadir CD4 counts $(10,11)$ and longer HIV infection (12) present a low bone mineral density (BMD). Furthermore, the increased levels of inflammatory cytokines such as TNF- $\alpha$ and IL 6 present in chronic HIV infection may increase bone turnover through osteoclast stimulation (13). Overall, HIV-infected individuals have an increased bone turnover (13). In antiretroviral therapy-naïve individuals, bone formation may be depressed and bone resorption increased. After initiation of antiretroviral therapy (ART), there is a recoupling of bone turnover, but the rate of bone remodeling remains increased (14). Bone biopsies were performed in few studies. Serrano and cols. (15) studied 22 ART-naive HIV-infected patients and found overall reduced bone formation, with decreased numbers of osteoclasts and without clinically significantly decreased BMD. Bone loss in HIV-infected individuals has also been associated with other metabolic disorders such as glucose intolerance, dyslipidemia, central fat accumulation (16) and decreased total body fat (17).

Antiretroviral therapy also seems to play an important role in the pathogenesis of bone loss in HIV-infected individuals. Experimental studies have demonstrated that nucleoside analog reverse transcriptase inhibitors (NRTIs) as well as protease inhibitors (PI) interfere in the bone microenvironment in different ways. Zidovudine has been shown to induce osteoclatogenesis and tenofovir to impair bone mineralization (18). PI impair the osteoblast and osteoclast functions by different mechanisms - blocking RANKL signaling, decreasing calcitriol activity, inhibiting osteoblast differentiation $(19,20)$. Cross-sectional studies have reported an increase in the frequency of BMD reduction in HIV-positive individuals taking ART $(21,22)$, especially with PI $(4,11)$. Following this, the association with NRTIs was also reported (23). However, other studies have not confirmed the association between a reduction in BMD with ART, nor with PI (24). In longitudinal studies, conflicting data regarding ART and BMD reduction have also been reported. When compared with healthy individuals, HIV-positive patients taking ART have a lower basal bone density, which remained stable during the evaluated period $(12,25)$. Clinical trials conducted with ART-naïve individuals, demonstrated a reduction in BMD during the monitoring period after beginning ART. These findings occurred not only in therapeutic regimens that specifically contained PI (26), but also in ART, irrespective of the type of antiretroviral (27), and so the association between BMD and PI has not been completely elucidated.

Although there is a certain controversy as to whether ART, specific drugs or a class of drugs are involved in the pathogenesis of bone loss in HIV-infected individuals, one meta-analysis indicated that the risk for patients taking ART was 2.4 times greater and for those on PI 1.5 times greater (4). It is worth highlighting that the studies included in this meta-analysis were made up of a predominantly male population. Very few studies have evaluated the risk of bone loss specifically in HIVinfected women $(7,8,28-35)$

Therefore, a literature review was carried out with the aim of clarifying certain questions surrounding osteoporosis in HIV-positive women, which to date have remained unanswered: (1) Is the occurrence of bone loss and fractures in HIV-positive women using ART/ PI higher when compared to non-users? (2) Is bone density in HIV-positive women using ART/PI lower than in non-users?

\section{METHODS}

\section{Strategy for screening and selecting studies}

The present review selected studies carried out on humans, with analytical, observational (cross-sectional, case-control and cohort) and intervention designs (controlled clinical trials and "before and after" studies), available on the databases of PubMed, EMBASE and Lilacs in English, Portuguese and Spanish. The research period covered was from 1987, when the first antiretroviral drug was approved by the FDA (36), until August 2009. No unpublished studies, abstracts of 
scientific events, dissertations and theses were included. The key-words were selected according to $\mathrm{MeSH}$ (Medical Subjects Heading Terms/PubMed): "HIV"; "Highly Active, Antiretroviral therapy" (HAART); "osteoporosis"; "Bone density" and "fracture, bones". On EMBASE, the description "Highly Active, Antiretroviral therapy" was recognized as "antiretrovirals". In order to identify the eligible studies, the key-words were cross-referenced, thus: "HIV and osteoporosis"; "HIV and bone density"; "HIV and fractures, bone"; "HAART and osteoporosis"; "HAART and bone density"; "HAART and fractures, bone".

\section{Data extraction}

Screening, selecting and extracting of data were conducted concomitantly by two independent investigators (EHC and TG), according to the protocol for conducting a systematic review by PRISMA (Preferred Reporting Items for Systematic reviews and Meta-Analyses) (37). In cases of discordance between the investigators, the complete text of the article was consulted and its eligibility was defined by consensus. Data from the selected article were extracted in a systemized form.

\section{Inclusion and exclusion criteria}

Studies were selected that included adult women (older than 18 years of age or a population report by the authors) and evaluated as primary or secondary endpoints, the occurrence of osteopenia/osteoporosis (according to WHO criteria), bone mineral density (by DXA, with the results in $\mathrm{g} / \mathrm{cm}^{2}$ ) or the occurrence of fractures (by $\mathrm{X}$-rays) associated to ART or PI. There was no minimum or maximum time limit for taking ART or PI. Studies that evaluated individuals of both sexes were selected for reading, and then included if the results for female patients were separately available. Studies were excluded if there were no available abstracts in the research database and on the site of the original journal as were studies that included male individuals only, children and adolescents. Studies were also excluded when they used other measures for evaluating bone mineral density other than the $\mathrm{t}$-score or $\mathrm{g} / \mathrm{cm}^{2}$ and those that evaluated occurrences of fractures by non-radiographic methods (X-ray).

\section{Outcome measurements}

WHO criteria were employed to characterize osteoporosis and osteopenia (2). The term "reduction of bone density" was used to designate the changes as a per- centage of the bone density in $\mathrm{g} / \mathrm{cm}^{2}$ in longitudinal studies. "Bone loss" means the presence of osteopenia and osteoporosis in studies that did not express the result of each category separately, irrespective of the site evaluated (lumbar spine, proximal femur and total body). Fractures were only considered as those which had been diagnosed by radiography.

\section{Synthesis and comparison of the studies}

The articles were systematically reviewed in relation to exposure: the use of ART (the use of any drug or combination of antiretroviral drugs that were not expressly in accordance with the class) and the use of PI (the use of any protease inhibitor). In the study by Huang and cols. (35) to evaluate the use of ART, data supplied for the use of NRTIs were considered since $100 \%$ of those on ART were also taking NRTIs. In relation to the outcome: the occurrence of osteoporosis and osteopenia, bone mineral density $\left(\mathrm{g} / \mathrm{cm}^{2}\right.$, calculating the difference of the groups), and the occurrence of fractures. In relation to the design of the studies: design (observational - cross-sectional or longitudinal - or intervention), objectives, inclusion and exclusion criteria. In relation to possible confounding factors: relating to HIV-infection (time of infection, CD4 and viral load), relating to the individual [age, menopause, BMI (body mass index) ethnicity/frequency of white individuals] and relating to life habits (current and previous use of alcohol, illicit drugs and smoking).

A narrative synthesis of the selected studies was conducted.

\section{RESULTS}

A total of five studies were identified. Screening from the PubMed, EMBASE and Lilacs databases provided 597 non-duplicated citations. Of these, 557 studies were excluded after evaluating the title or the abstract, since they did not comply with the inclusion criteria or contained at least one of the exclusion criteria. Of the 40 articles selected for detailed analysis, 32 had been conducted with patients of both sexes (10-12,2126,38-58) and only eight (8,28-30,32-35) had been conducted with a totally female population. The selection process finished with four studies which included only women $(28,33-35)$ and one study with a population of both sexes in which the results for men and women were presented separately (38). The complete selection process is described in figure 1 . 


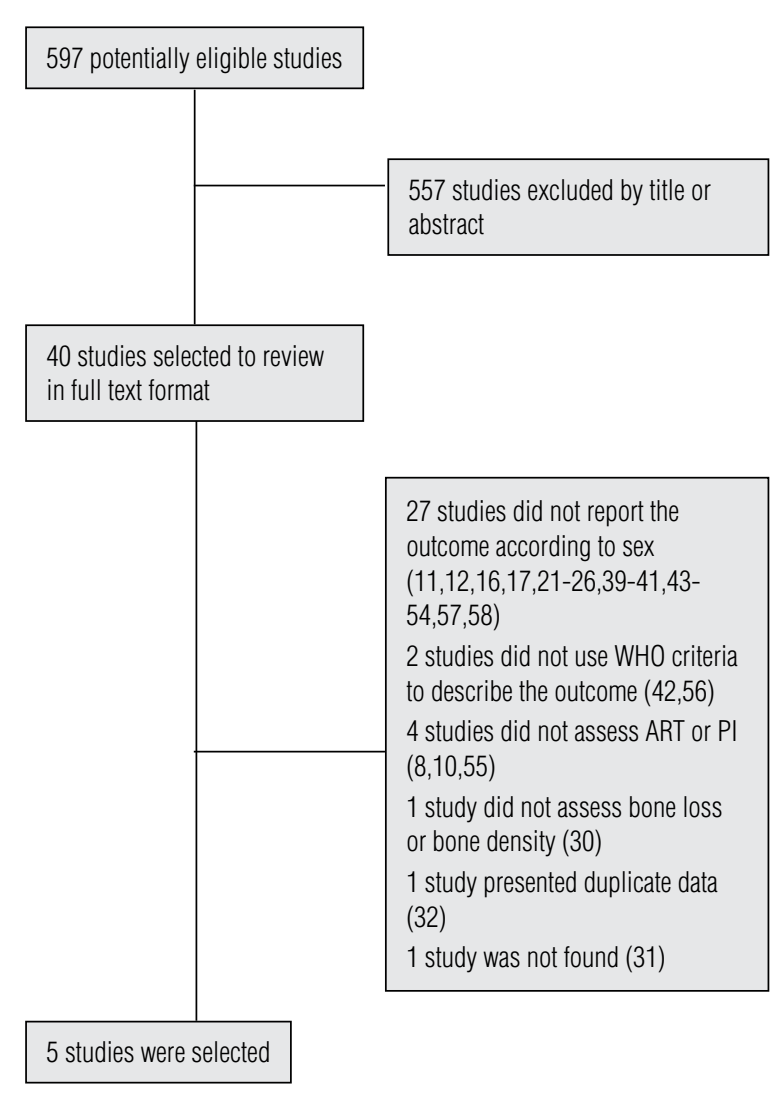

Figure 1. Complete selection process of studies.

\section{General characteristics of the studies and the studied population}

Tables 1 and 2 contain the main characteristics of the selected studies and the studied populations, respectively. The majority of the studies were cross-sectional (80\%). All had been published in English and conducted with North American women, except for the multicentric clinical trial (38). Only one study had primarily been designed to respond to the same questions as this systematic review (28). The other contained secondary information regarding the influence of ART on bone mass in HIV-positive women (33-35,38) (Table 1).

None of the four studies evaluated only HIV-infected women (28,33-35). The mean age ranged from 37 to 56 years, and in the majority of studies the mean age was above 40 years of age (Table 2). The inclusion and exclusion criteria differed among studies and are displayed in table 2 .

\section{Studies outcomes and exposures}

In relation to the outcomes of the selected studies, three $(60 \%)$ presented bone density in accordance with WHO criteria amongst female users and non-users of
ART/PI $(28,33,35)$. Of these, one study provided data grouping both the lumbar spine (LS) and proximal femur (PF) (28), another considered data from the lumbar spine only (33) and another, data from the proximal femur only (35). Information regarding BMD in $\mathrm{g} / \mathrm{cm}^{2}$ was available in three out of the five studies $(28,34,35)$. In the clinical trial, the only data provided was the percentage difference between the initial whole body BMD values of all women included in the study and at the end of the monitoring period (38). Only one study evaluated fracture by X-ray (33).

In relation to the exposures of particular interest to the present review, three studies evaluated the outcomes in relation to the use of ART $(33,35,38)$, and two to the use of PIs $(28,34)$.

Table 3 shows a summary of the outcomes and exposure variables considered by the authors to describe the population of HIV-infected patients in the various studies. These risk factors either classical or HIV-associated have not been categorized by the use of ART or PI since this information was not available in all the studies. Some data referring to the study by Anastos and cols. (28) do not appear on the table since they were supplied for the four evaluated exposition groups (HIV-negative, HIV-positive patients ART-naïve, HIV-positive patients using ART but not PI and HIVpositive patients using ART with PI). Thus, it was decided not to aggregate the values, given that it would be necessary to calculate the mean values.

The study by Anastos and cols. (28) reported that patients on ART presented lower CD4 nadir counts and a greater viral load, both statistically significant when compared to those not using ART (numerical data not available). With regard to risk factors related to the patients, post-menopausal factors were only described in two of the studies $(28,33)$. Yin and cols. (33) only included post-menopausal women in their study. Anastos and cols. (28) studied a higher number of postmenopausal women on ART/PI regimen than those on ART without PI $(\mathrm{p}<0.001)$. With regard to BMI, only in the study that evaluated women with wasting syndrome based on weight loss the mean value of BMI was $21.5(+/-3.5) \mathrm{kg} / \mathrm{m}^{2}(35)$. In the other, the mean BMI was between $25-30 \mathrm{~kg} / \mathrm{m}^{2}$, that is, in overweight patients $(33,34)$. In the studies reporting the ethnicity of the participants the majority was categorized as "non-white", of predominantly African-American and Hispanic origins $(28,33,34)$. Not all studies provided data concerning use of toxic substances (Table 3 ). 
Table 1. Selected studies: location, language, study design and objectives

\begin{tabular}{|c|c|c|c|c|}
\hline Author/year & Location & Language & Study design/follow up & Objectives \\
\hline Brown and cols. (38), 2009 & $\begin{array}{l}\text { United States, Canada, } \\
\text { France, Spain and United } \\
\text { Kingdom }\end{array}$ & English & $\begin{array}{l}\text { Randomized Clinical trial } \\
\text { open label/96 weeks }\end{array}$ & $\begin{array}{l}\text { Evaluate changes in BMD prospectively in antiretroviral- } \\
\text { naive persons initiating a PI versus a NNRTI-based } \\
\text { regimen; determine whether removal of ZDV/3TC backbone } \\
\text { impacts BMD; identify factors associated with BMD loss } \\
\text { over } 96 \text { weeks, including systemic inflammation }\end{array}$ \\
\hline Anastos and cols. (28), 2007 & United States & English & Cross-sectional & $\begin{array}{l}\text { Verify association of BMD with HIV infection and HIV } \\
\text { therapy in women enrolled in the Women's Interagency HIV } \\
\text { Study (WIHS) }\end{array}$ \\
\hline Yin and cols. (33), 2005 & United States & English & Cross-sectional & $\begin{array}{l}\text { Assess risk factors for osteoporosis and measured BMD } \\
\text { and biochemical indices of mineral metabolism in a group } \\
\text { of HIV-infected post-menopausal women }\end{array}$ \\
\hline Dolan and cols. (34), 2004 & United States & English & Cross-sectional & $\begin{array}{l}\text { Investigate bone density and associated factors in normal } \\
\text { weight, ambulatory HIV-infected women }\end{array}$ \\
\hline Huang and cols. (35), 2001 & United States & English & Cross-sectional & $\begin{array}{l}\text { Determine the risk factors for osteopenia in androgen- } \\
\text { deficient women with Aids syndrome wasting }\end{array}$ \\
\hline
\end{tabular}

BMD: bone mineral density; NNRTI: non-nucleoside reversal transcriptase inhibitor; ZDV: zidovudine; 3TC: lamivudine; HIV: human immunodeficiency virus; Aids: acquired immunodeficiency syndrome.

Table 2. Selected studies: sample size, number of participants with and without HIV infection, number of female participants, age means of female HIVinfected participants, inclusion and exclusion criteria

\begin{tabular}{|c|c|c|c|c|c|c|}
\hline Author/year & $\begin{array}{c}\text { Sample N } \\
\text { begin/ } \\
\text { end }\end{array}$ & $\begin{array}{l}\operatorname{HIV}(+) / \\
\operatorname{HIV}(-)\end{array}$ & $\begin{array}{l}\text { Women, N } \\
\text { (\%) }\end{array}$ & Aget(SD) & Inclusion criteria & Exclusion criteria \\
\hline $\begin{array}{l}\text { Brown and } \\
\text { cols. (38), } 2009\end{array}$ & $155 / 106$ & $155 / 0$ & $34(22)$ & - & $\begin{array}{l}\text { Antiretroviral-naïve HIV-infected subjects with } \\
\text { plasma HIV-1 RNA } \geq 1000 \text { copies/mL; } \\
\text { absence of documented resistance to study } \\
\text { drugs; no evidence of acute illness }\end{array}$ & $\begin{array}{l}\text { Treatment to Aids defining opportunistic } \\
\text { infection within } 30 \text { days; medical history that } \\
\text { in the opinion of the investigator adversely } \\
\text { affected his/her participation in this study }\end{array}$ \\
\hline $\begin{array}{l}\text { Anastos and } \\
\text { cols. (28), } 2007\end{array}$ & 426/NA & $274 / 152$ & $426(100)$ & $-^{\star}$ & $\begin{array}{l}\text { Women participants of Women's Interagency } \\
\text { HIV Study cohort enrolled in April } 2001 \text { to } \\
\text { October } 2005\end{array}$ & $\begin{array}{l}\text { Type } 1 \text { diabetes; weight > } 264 \text { pounds; use of } \\
\text { corticosteroids, drugs to treat osteoporosis; } \\
\text { exogenous hormones, including oral } \\
\text { contraceptives }\end{array}$ \\
\hline $\begin{array}{l}\text { Yin and cols. } \\
(33), 2005\end{array}$ & $217 / N A$ & $31 / 186$ & $217(100)$ & $56(1)$ & $\begin{array}{l}\text { HIV-infected post-menopausal women } \\
\text { (history of amenorrhea }>1 \text { year; with FSH } \\
>30 \mathrm{mIU} / \mathrm{mL} \text {, or FSH }>20 \mathrm{mlU} / \mathrm{mL} \text { with } \\
\text { estradiol }<30 \mathrm{pg} / \mathrm{mL} \text { or age }>55 \text { years). } \\
\text { Historical controls matched by ethnicity } \\
\text { and age }\end{array}$ & $\begin{array}{l}\text { History of disorders known to affect the } \\
\text { skeleton; multiple myeloma or other } \\
\text { malignancies metastatic to the skeleton; renal } \\
\text { insufficiency; previous osteoporosis or } \\
\text { history of treatment with bysphosphonates, } \\
\text { selective estrogen receptor modulators or } \\
\text { calcitonin }\end{array}$ \\
\hline $\begin{array}{l}\text { Dolan and cols. } \\
\text { (34), } 2004\end{array}$ & $147 / N A$ & $84 / 63$ & $147(100)$ & $44(1)$ & $\begin{array}{l}\text { Women with age between } 18 \text { and } 60 \text { years; } \\
\mathrm{BMI} \text { of } 20-35 \mathrm{~kg} / \mathrm{m}^{2} \text {. If HIV-infected, stable } \\
\text { antiretroviral regimen within } 6 \text { weeks }\end{array}$ & $\begin{array}{l}\text { Use of megestrol acetate, ketoconazole, } \\
\text { antidiabetic agents, hormone replacement } \\
\text { therapy, bysphosphonates, steroids, growth } \\
\text { hormone, oral contraceptive, } \\
\text { medroxyprogesterone, progesterone } \\
\text { intrauterine insert, testosterone or anabolic } \\
\text { agents within } 3 \text { months. Substance abuse, } \\
\text { pregnancy, breastfeeding in the past year, or } \\
\text { oophorectomy and bone diseases }\end{array}$ \\
\hline $\begin{array}{l}\text { Huang and } \\
\text { cols. (35), } 2001\end{array}$ & 49/NA & $28 / 21$ & $49(100)$ & $37(4)$ & $\begin{array}{l}\text { Women with low free testosterone level } \\
(\leq 3 \mathrm{pg} / \mathrm{mL}) \text {; with age between } 18-45 \text { years; } \\
\text { weight } \leq 90 \% \text { of IBW, loss of } \geq 10 \% \text { of } \\
\text { maximum weight, loss } \geq 5 \% \text { if weight } \\
<100 \% \text { of IBW; with current use of birth } \\
\text { control (IUD or barrier method) }\end{array}$ & $\begin{array}{l}\text { Use of androgen, contraceptives, anabolic } \\
\text { agents with in the past } 3 \text { months; pregnancy; } \\
\text { breastfeeding, new opportunistic infection } \\
\text { within } 4 \text { weeks of the study; new antiretroviral } \\
\text { therapy within } 6 \text { weeks of the study; use of } \\
\text { corticoids, liver disease, renal disease, } \\
\text { hemoglobin < } 8 \mathrm{~g} / \mathrm{dl} \text { and substance or } \\
\text { alcohol abuse }\end{array}$ \\
\hline
\end{tabular}

$\mathrm{N}$ : number of individuals on sample; SD: standard deviation; $\uparrow$ : age means of HIV-infected women; IBW: ideal body weight; NA: Not applicable. *: aggregated age mean of all HIV-infected women waS not provided; FSH: follicular stimulant hormone; RNA: ribonucleic acid; BMI: body mass index; HIV: human immunodeficiency virus; Aids: acquired immunodeficiency syndrome. 
Table 3. Selected studies: outcomes and exposures studied, traditional and HIV-related risk factors in HIV-infected women

\begin{tabular}{|c|c|c|c|c|c|c|c|c|c|c|c|}
\hline Author/year & $\begin{array}{l}\text { Outcomes } \\
\text { assessed }\end{array}$ & $\begin{array}{l}\text { Exposures } \\
\text { assessed }\end{array}$ & $\begin{array}{c}\text { Duration of } \\
\text { HIV infection } \\
\text { (year) }\end{array}$ & CD4 (SD) & $\begin{array}{l}\text { Undetectable } \\
\text { viral load (\%) }\end{array}$ & $\begin{array}{c}\text { Postmenopausal } \\
\text { N (\%) }\end{array}$ & BMI (SD) & $\begin{array}{c}\text { White race } \\
\text { N (\%) }\end{array}$ & $\begin{array}{c}\text { Smoking } \\
\text { N (\%) }\end{array}$ & $\begin{array}{c}\text { Substance } \\
\text { abuse N } \\
\text { (\%) }\end{array}$ & $\begin{array}{c}\text { Alcohol } \\
\text { consume } \\
\mathrm{N}(\%)\end{array}$ \\
\hline $\begin{array}{l}\text { Brown and } \\
\text { cols. (38), } \\
2009\end{array}$ & $\mathrm{BMD}\left(\mathrm{g} / \mathrm{cm}^{2}\right)$ & ART & - & - & - & - & - & - & - & - & - \\
\hline $\begin{array}{l}\text { Anastos and } \\
\text { cols. (28), } \\
2007\end{array}$ & $\begin{array}{c}\% \text { OPN/OP } \\
\text { BMD }\left(\mathrm{g} / \mathrm{cm}^{2}\right)\end{array}$ & PI & - & $\star *$ & - & $73(26.3)$ & $\star \star$ & $54(19.7)$ & - & $58(21.2)$ & $34(18.9) \dagger$ \\
\hline $\begin{array}{l}\text { Yin and cols. } \\
(33), 2005\end{array}$ & $\%$ OPN/OP & ART & - & - & - & $31(100)$ & $26.0(1)$ & $0(0)$ & $13(41.9)$ & - & $9(29) \ddagger$ \\
\hline $\begin{array}{l}\text { Dolan and } \\
\text { cols. (34), } \\
2004\end{array}$ & $\mathrm{BMD}\left(\mathrm{g} / \mathrm{cm}^{2}\right)$ & PI & 8 & $385(25)$ & $42 \%^{\varepsilon}$ & - & $26.0(0.6)$ & $33(39)$ & $37(44)$ & $34(40)$ & - \\
\hline $\begin{array}{l}\text { Huang and } \\
\text { cols. (35), } \\
2001\end{array}$ & $\begin{array}{c}\% \text { OPN/OP } \\
\text { BMD }\left(\mathrm{g} / \mathrm{cm}^{2}\right)\end{array}$ & ART & - & 335 (192) & $37 \%^{*}$ & - & $21.5(3.5)$ & - & - & - & - \\
\hline
\end{tabular}

$\mathrm{N}$ : number of individuals; BMI: body mass index; SD: standard deviation; BMD: bone mineral density; OPN: osteopenia; OP: osteoporosis; ART: antiretroviral therapy; PI: protease inhibitor; †: current alcohol use > $16 \mathrm{~g} /$ day; $\neq$ : alcohol use of 1 drink/day; $£:<50$ copies/ml HIV-1 RNA; $¥:<400$ copies/ml HIV-1 RNA; ** Aggregate data for all HIV-positive women was not provided.

\section{Bone mineral density data in patients on ART/PI}

\section{Osteoporosis/osteopenia in women on ART/PI}

As mentioned above the frequency of osteoporosis and osteopenia according to WHO criteria (2) was described in three of the five studies selected $(28,33,35)$. However, the data supplied by these studies differed not only in relation to the involved site (LS, PF or both) but also with regard to their exposure (ART or PI) and therefore could not be grouped (Table 4).

Anastos and cols. (28), in a cross-sectional study with 426 women, some of whom were HIV-infected $(\mathrm{n}=274)$, others uninfected $(\mathrm{n}=152)$, found osteopenia at LS and femoral neck (FN) in $22 \%$ of the women on PI and in $14 \%$ of those not (statistical analysis not provided). Osteoporosis of the LS and of the FN was present in $7.3 \%$ of the patients taking PI and in $4 \%$ of those not taking it. However, this difference was not statistically significant.

Yin and cols. (33), studying 217 postmenopausal women with $(\mathrm{n}=31)$ and without $(\mathrm{n}=186)$ HIV, reported LS osteoporosis in $42.8 \%$ of women on ART and in $33 \%$ of HIV-infected women not using ART. In this study, no statistical analysis was carried out with regard to the use and non-use of ART. In a univariate analysis, no association was found between LS and FP osteoporosis and the different classes of ART (numerical data not provided).

Huang and cols. (35) conducted a study with women with relative androgen deficiency, with HIV and wasting syndrome $(\mathrm{n}=28)$ and without HIV $(\mathrm{n}=21)$. There was no difference between the frequencies of os- teopenia and osteoporosis in the FN amongst users and non-users of ART ( $\mathrm{p}=0.68 \mathrm{e} \mathrm{p}=1$, respectively).

\section{Bone density $\left(\mathrm{g} / \mathrm{cm}^{2}\right)$ in women on ART/PI}

A quantitative evaluation of bone mass was conducted in four of the five studies selected $(28,33,34,38)$ (Table 5 ). There was only one longitudinal study (38) and this demonstrated a decrease of $2.2 \%$ in whole body BMD in HIV-positive women over a period of 96 weeks (statistical analysis not provided). A clinical trial selected HIV-positive ART-naïve to start ART with PI (lopinavir/r) or ART with NNRTI (efavirenz). In this study the characteristics of the female population were not expressed separately.

Amongst the cross-sectional studies, two evaluated bone mass in relation to the use of PI $(28,34)$ and one study in relation to the use of ART (35). Anastos and cols. (28) demonstrated a difference greater than $3 \%$ in the BMD amongst women on PI when compared to those not on PI, in the LS as well as the femoral neck. However, the difference was statistically significant only in the FN after adjustment for race, BMI nadir, menopausal status and years of smoking $(\mathrm{p}=0.014)$. Dolan and cols. (34) did not show any difference in the BMDs of those taking PI when compared to those not taking it, neither in the LS $(\mathrm{p}=0.9)$ nor in the FP $(\mathrm{p}=0.55)$.

The only cross-sectional study to evaluate BMD in relation to the use of ART reported a difference of more than $12 \%$ in the $\mathrm{FN}(\mathrm{p}=0.04)$ and no difference in the LS (statistic analysis not provided) of users when compared to non-users. In this study, all women with HIV had recently lost weight (35). 
Table 4. Selected studies: osteopenia and osteoporosis in lumbar spine and proximal femur according ART or PI use in HIV-infected women

\begin{tabular}{|c|c|c|c|c|c|c|c|c|}
\hline \multirow[b]{2}{*}{ Author/year } & \multirow[b]{2}{*}{ Exposure } & \multirow[b]{2}{*}{$\mathbf{N}$} & \multicolumn{3}{|c|}{ Osteopenia (\%) } & \multicolumn{3}{|c|}{ Osteoporosis (\%) } \\
\hline & & & $\begin{array}{l}\text { Lumbar } \\
\text { spine (LS) }\end{array}$ & $\begin{array}{l}\text { Proximal } \\
\text { femur (PF) }\end{array}$ & $\mathbf{L S}+\mathbf{P F}$ & $\begin{array}{l}\text { Lumbar } \\
\text { spine (LS) }\end{array}$ & $\begin{array}{l}\text { Proximal } \\
\text { femur (PF) }\end{array}$ & LS + PF \\
\hline \multirow[t]{2}{*}{ Anastos and cols. (28), 2007} & $\mathrm{Pl}(+)$ & 97 & - & - & 22 & - & - & 7.3 \\
\hline & $\mathrm{PI}(-)$ & 101 & - & - & 14 & - & - & 4.0 \\
\hline \multirow[t]{2}{*}{ Yin and cols. (33), 2005} & ART $(+)$ & 28 & - & - & - & 42.8 & - & - \\
\hline & ART (-) & 3 & - & - & - & 33.3 & - & - \\
\hline \multirow[t]{2}{*}{ Huang and cols. (35), 2001} & $\operatorname{ART}(+)^{*}$ & 21 & - & 40.0 & & & 5.0 & \\
\hline & ART (-) & 7 & & 28.6 & & & 0.0 & \\
\hline
\end{tabular}

N: sample size; PI: protease inhibitor; ART: antiretroviral therapy. * In this study, NRTI use was considered similar to ART use.

Table 5. Selected studies: bone mineral density (BMD) of lumbar spine, proximal femur and whole body according ART or PI use in HIV-infected women

\begin{tabular}{|c|c|c|c|c|c|c|c|c|c|c|c|}
\hline \multirow[b]{2}{*}{ Author/year } & \multirow[b]{2}{*}{ Exposure } & \multirow{2}{*}{$\begin{array}{l}\text { N (lumbar } \\
\text { spine/ } \\
\text { proximal } \\
\text { femur) }\end{array}$} & \multicolumn{9}{|c|}{ BMD mean, $\mathbf{g} / \mathrm{cm}^{2}$ (SD) } \\
\hline & & & $\begin{array}{l}\text { Lumbar } \\
\text { spine }\end{array}$ & $\mathbf{p}$ & Diff. (\%) & $\begin{array}{l}\text { Proximal } \\
\text { femur }\end{array}$ & p & Diff. (\%) & $\begin{array}{l}\text { Total } \\
\text { body }\end{array}$ & $\mathbf{p}$ & Diff. (\%) \\
\hline \multicolumn{12}{|l|}{ Cross-sectional studies } \\
\hline \multirow{2}{*}{$\begin{array}{l}\text { Anastos and cols. (28), } \\
2007\end{array}$} & $\mathrm{Pl}(+)$ & $93 / 97$ & $1.22(0.019)$ & 0.086 & -3.17 & $1.00(0.016)^{\star}$ & 0.014 & -4.76 & - & - & - \\
\hline & $\mathrm{PI}(-)$ & $98 / 101$ & $1.26(0.018)$ & & & $1.05(0.015)^{\star}$ & & & & & \\
\hline \multirow{2}{*}{$\begin{array}{l}\text { Dolan and cols. (34), } \\
2004\end{array}$} & $\mathrm{Pl}(+)$ & $34 / 34$ & $1.02(0.02)$ & 0.9 & 0.0 & $0.94(0.02) \ddagger$ & 0.55 & +2.13 & - & - & - \\
\hline & $\mathrm{PI}(-)$ & $49 / 49$ & $1.02(0.02)$ & & & $0.92(0.02) \ddagger$ & & & & & \\
\hline \multirow{2}{*}{$\begin{array}{l}\text { Huang and cols. (35), } \\
2001\end{array}$} & ART $(+) \dagger$ & $-/ 21$ & - & - & & $0.76(0.12)^{\star}$ & 0.04 & -12.64 & - & - & - \\
\hline & ART (-) & $-/ 7$ & - & - & & $0.87(0.11)^{\star}$ & & & & & \\
\hline \multicolumn{12}{|l|}{ Clinical trial } \\
\hline \multirow{2}{*}{$\begin{array}{l}\text { Brown and cols. (38), } \\
2009\end{array}$} & $\operatorname{ART}(+)$ & & - & - & - & - & - & - & - & - & -2.2 \\
\hline & ART (-) & & & & & & & & & & \\
\hline
\end{tabular}

SD: standard deviation; N: number of participants; p: statistical significance; diff: difference; PI: protease inhibitor; ART: antiretroviral therapy.

$\mathrm{N}$ : number of individuals; Total body: bone mineral content; $\uparrow$ In this study, NRTI use was consider similar to ART use; * Femural neck; $\ddagger$ Total femur.

\section{Fractures in women on ART/PI}

Only one study evaluated osteoporotic fractures by spinal X-ray, after screening by IVA (Instant Vertebral Assessment), during DXA. One HIV-positive woman presented a vertebral compression fracture. No information was provided concerning the use of ART or PI (33).

\section{DISCUSSION}

The present review included four cross-sectional studies and one clinical trial with the aim of evaluating bone mineral density and fractures in HIV-infected women using ART or PI. This review has demonstrated that there is a difference of over $3 \%$ in the BMD in the $\mathrm{FN}$ of HIV-infected women using PI and ART. The studies revealed no differences in the BMD of the LS between patients using PI and ART and those not using. One important fact is that no studies were designed to compare the use and non-use of PI in HIV-positive women.
The lack of studies that have employed image methods in order to evaluate fragility fractures rendered it impossible to draw any conclusion regarding this outcome.

Although a meta-analysis demonstrated the association of ART and PI with osteoporosis and osteopenia in HIV-infected individuals irrespective of sex (4) until the present time there have been no consensual data that confirm an association in HIV-infected women. In this review, one of the selected studies documented that the risk of osteoporosis was four times greater in HIV-infected women using PI. However, the reference group for calculating the odds ratio (OR) was made up of HIV-negative women and not HIV-infected women not using PI (28). No other study calculated measures of association for osteopenia and osteoporosis in relation to the use of ART or PI. The various different forms of describing data amongst the selected studies provided difficulties for systematizing, tabulating results and interpreting the extracted data. This diversity 
also occurred in relation to the presented results regarding the variety of sites studied. The clinical consequences of bone loss in the PF are quite distinct from bone loss in the LS and not all the studies supplied data for all the evaluated sites. Furthermore, although the reported frequencies of osteopenia and osteoporosis were higher in those taking antiretroviral drugs, the majority of the studies did not provide any statistical analysis of the differences in prevalence, therefore rendering it impossible to confirm whether or not ART is associated to bone loss.

Some of the selected studies did not evaluate osteoporosis and osteopenia $(34,38)$, but rather the difference between the BMD of women with or without the use of ART or PI. The majority demonstrated lower femoral neck BMD in women using ART/PI when compared to HIV-infected not using ART/PI. It is important to highlight that all the studies included in this review that reported this difference were crosssectional, which makes it impossible to state whether lower BMD actually resulted from the use of the drugs (causal inference). One exception was the study by Brown and cols. (38), a longitudinal study on HIVinfected women before and after the introduction of ART. However, this study reported did not provide the statistical analysis of the differences. Nevertheless, these results are consistent with recent clinical trials which have shown a reduction in BMD after the introduction of ART or PI in a population including both men and women $(26,27)$.

The main concern when osteopenia and osteoporosis are diagnosed is to prevent fragility fractures. Population studies have demonstrated that HIV-positive patients report a higher prevalence of fragility fractures (30) and secondary data taken from health system records (59) confirm the same when HIV-infected women are compared to HIV-negative women. However, to date, no study has evaluated if the use of ART or PI is related to a higher prevalence of fractures, confirmed by X-ray, specifically in HIV-infected women.

In relation to the limitations of the present review, it should be mentioned that it was impossible to access one of the studies selected by title from the EMBASE database and for which there was no abstract; however, the title suggested that it had studied the role of ART on bone mass in women (Figure 1). One other limiting aspect refers to the differences in the population characteristics of the studies included and of the lack of a standardized description of the studied results.
Moreover, it is possible that the evidence produced by some of the selected studies may be subject to bias. All the cross-sectional studies were designed to compare HIV-infected and non-HIV infected individuals. Thus, it is possible that the internal comparison of the group of HIV-infected individuals was subject to random errors due to the small sample size (28,33-35). The selected studies $(28,33-35,38)$ made no adjustments to the results in accordance with all the well-known, traditional risk factors for osteoporosis, therefore we were unable to see whether the results were in consequence of the exposures or of the possible confounding factors. Although the majority of the studies had conducted a multivariate analysis some of them $(34,35,38)$ did not actually state if this statistical control had been carried out specifically during the analysis of the exposures and the outcomes evaluated in this review.

Finally, it is important to emphasize the lack of evidence regarding the role of ART and PI in the occurrence of osteoporosis and osteopenia, specifically in HIV-infected women. Certain considerations may indicate directions for future studies, which may go some way to clarifying this question: (a) longitudinal studies may verify this association using HIV-positive women without the previous use of ART or PI as a control group; (b) the use of WHO criteria to define osteoporosis and osteopenia is important in order to standardize the studied outcomes; (c) studies designed to verify the occurrence of fractures related to the use or nonuse of antiretrovirals, the use of image methods, may contribute to clarifying the clinical repercussions of osteoporosis in HIV-positive women; (d) the inclusion of traditional risk factors for osteoporosis as well as other possible associated factors such as the deficiency or insufficiency of vitamin $\mathrm{D}$, could help to provide a more efficient control over the possible confusion factors.

Disclosure: no potential conflict of interest relevant to this article was reported.

\section{REFERENCES}

1. Consensus Development Conference. Diagnosis, prophylaxis, and treatment of osteoporosis. Am J Med. 1993;94:646-50.

2. World Health Organization - Assessment of fracture risk and its application to screening for postmenopausal osteoporosis. WHO technical report series 1994; Geneva, 843:1-129.

3. Hui SL, Slemenda CW, Jonhston CC Jr. Age and bone mass as predictors of fracture in a prospective study. J Clin Invest. 1988;81:1804-9. 
4. Brown TT, Qaqish RB. Antiretroviral therapy and the prevalence of osteopenia and osteoporosis: a meta-analytic review. AIDS. 2006;20(17):2165-74.

5. Tebas P, Powderly WG, Claxton S, Marin D, Tantisiriwat W, Teitelbaum SL, et al. Accelerated bone mineral loss in HIV-infected patients receiving potent antiretroviral therapy. AIDS. 2000;14(4):63-7.

6. Amiel C, Ostertag A, Slama L, Baudoin C, N'Guyen T, Lajeunie E, et al. BMD is reduced in HIV-infected men irrespective of treatment. J Bone Miner Res. 2004;19:402-9.

7. Teichmann J, Stephan E, Lange U, Discher T, Friese G, Lohmeyer J, et al. Osteopenia in HIV-infected women prior to highly active antiretroviral therapy. J Infect. 2003;46:221-7.

8. Arnsten JH, Freeman R, Howard AA, Floris-Moore M, Santoro N, Schoenbaum EE. HIV infection and bone mineral density in middle-aged women. Clin Infect Dis. 2006;42(7):1014-20.

9. Bolland MJ, Grey AB, Gamble GD, Reid IR. Low body weight mediates the relationship between HIV infection and low bone mass density: a meta-analysis. J Clin Endocrinol Metab. 2007;92(12):4522-8.

10. Cazanave C, Dupon M, Lavignolle-Aurillac V, Barthe N, LawsonAyayi S, Mehsen N, et al; Groupe d'Epidémiologie Clinique du SIDA en Aquitaine. Reduced bone mineral density in HIV-infected patients: prevalence and associated factors. AIDS. 2008;22(3):395-402.

11. Madeddu G, Spanu A, Solinas P, Calia GM, Lovigu C, Chessa F, et al. Bone mass loss and vitamin D metabolism impairment in HIV patients receiving highly active antiretroviral therapy. $\mathrm{O} \mathrm{J} \mathrm{Nucl}$ Med Mol Imaging. 2004;48(1):39-48.

12. Mondy K, Yarasheski K, Powderly WG, Whyte M, Claxton S, et al. Longitudinal evolution of bone mineral density and bone markers in human immunodeficiency virus-infected individuals. Clin Infect Dis. 2003;36(4):482-90.

13. Aukrust $P$, Huag C, UelandT, Lien E, Müller F, EspevikT, et al. Decreased bone formative and enhanced resorptive markers in human immunodeficiency virus infection: indication of normalization of the bone-remodeling process during highly active antiretroviral therapy. J Clin Endocrinol Metab. 1999;84(1):145-50.

14. Yin MT, Shane E. Low bone-mineral in patients with HIV: pathogenesis and clinical significance. Curr Opin Endocrinol Diabetes. 13:497-502.

15. Serrano S, Marinoso ML, Soriano JC, Rubiés-Prat J, Aubia J, Coll J, et al. Bone remodeling in human immunodeficiency virus-1-infected patients: a histomophometric study. Bone. 1995;16:185-91.

16. Brown TT, Ruppe MD, Kassner R, Kumar P, Kehoe T, Dobs AS, et al. Reduced bone mineral density in human immunodeficiency virus-infected patients and its association with increased central adiposity and postload hyperglycemia. J Clin Endocrinol Metab. 2004;89(3):1200-6.

17. Tsekes G, Chrysos G, Douskas G, Paraskeva D, Mangafas N, Giannakopoulos $D$, et al. Body composition changes in protease inhibitor-naive HIV-infected patients treated with two nucleoside reverse transcriptase inhibitors. HIV Med. 2002;3(2):85-90.

18. Pan G, Yang Z, Ballinger SW, McDonald JM. Pathogenesis of osteopenia/osteoporosis induced by highly active anti-retroviral therapy for AIDS. Ann NY Acad Sci. 2006;1068:297-308.

19. Wang MW, Wei S, Faccio R, Takeshita S, Tebas P, Powderly WG, et al. The HIV protease inhibitor ritonavir blocks osteoclastogenesis and function by impairing RANKL-induced signaling. J Clin Invest. 2004;114:206-13.

20. Amorosa V, Tebas P. Bone disease and HIV infection. Clin Infect Dis. 2006:42:108-14.

21. Vescini F, Borderi M, Buffa A, Sinicropi G, Tampellini L, Chiodo F, et al. Bone mass in HIV-infected patients: focus on the role of therapy and sex. J Acquir Immune Defic Syndr. 2003;33(3):405-7.

22. Knobel H, Guelar A, Vallecillo G, Nogués $X$, Díez A. Osteopenia in HIV-infected patients: is it the disease or is it the treatment? AIDS. 2001;15(6):807-8.
23. Gallant JE, Staszewski S, Pozniak AL, DeJesus E, Suleiman JM, et al; 903 Study Group. Efficacy and safety of tenofovir DF vs stavudine in combination therapy in antiretroviral-naive patients: a 3-year randomized trial. JAMA. 2004;292(2):191-201.

24. Bruera D, Luna N, David DO, Bergoglio LM, Zamudio J. Decreased bone mineral density in HIV-infected patients is independent of antiretroviral therapy. AIDS. 2003;17(13):1917-23.

25. Fernández-Rivera J, García R, Lozano F, Macías J, García-García $\mathrm{JA}$, Mira JA, et al. Relationship between low bone mineral density and highly active antiretroviral therapy including protease inhibitors in HIV-infected patients. HIV Clin Trials. 2003;4(5):337-46.

26. Duvivier C, Kolta S, Assoumou L, Ghosn J, Rozenberg S, Murphy, et al; ANRS 121 Hippocampe study group. Greater decrease in bone mineral density with protease inhibitor regimens compared with nonnucleoside reverse transcriptase inhibitor regimens in HIV-1 infected naive patients. AIDS. 2009;23(7):817-24.

27. Mallon PW, Miller J, Cooper DA, Carr A. Prospective evaluation of the effects of antiretroviral therapy on body composition in HIV-1infected men starting therapy. AIDS. 2003;17:971-9.

28. Anastos K, Lu D, Shi O, Mulligan K, Tien PC, Freeman R, et al. The association of bone mineral density with HIV infection and antiretroviral treatment in women. AntivirTher. 2007;12(7):1049-58.

29. Dolan SE, Carpenter S, Grinspoon S. Effects of weight, body composition, and testosterone on bone mineral density in HIV-infected women. J Acquir Immune Defic Syndr. 2007;45:161-7.

30. Prior J, Burdge D, Maan E, Milner R, Hankins C, Klein M, et al. Fragility fractures and bone mineral density in HIV positive women: a case-control population-based study. Osteoporos Int. 2007;18(10):1345-53.

31. Libois A, Clumeck N, Kabeya K, Gerard M, De Wit S, Poll B, et al. Risk factors of osteopenia in HIV-infected women: no role of antiretroviral therapy. Maturitas. 2010;65(1):51-4. Epub 2009 Nov 24.

32. Dolan SE, Kanter JR, Grinspoon S. Longitudinal analysis of bone density in human immunodeficiency virus-infected women. J Clin Endocrinol Metab. 2006;91(8):2938-45.

33. Yin M, Dobkin J, Brudney K, Becker C, Zadel JL, Manandhar M, et al. Bone mass and mineral metabolism in HIV+ postmenopausal women. Osteoporos Int. 2005;16(11):1345-52.

34. Dolan SE, Huang JS, Killilea KM, Sullivan MP, Aliabadi N, Grinspoon S. Reduced bone density in HIV-infected women. AIDS 2004;18(3):475-83.

35. Huang JS, Wilkie SJ, Sullivan MP, Grinspoon S. Reduced bone density in androgen-deficient women with acquired immune deficiency syndrome wasting. J Clin Endocrinol Metab. 2001;86(8):3533-39.

36. Sepkowitz KA. Aids - The first 20 years. N Eng J Med. 2001; 344(23):1764-72.

37. Liberati A, Altman DG, Tetzlaff J, Mulrow C, Gøtzsche PC, loannidis JP, et al. The PRISMA statement for reporting systematic reviews and meta-analyses of studies that evaluate health care interventions: explanation and elaboration. Ann Intern Med. 2009;151(4):W65-94.

38. Brown TT, McComsey GA, King MS, Qaqish RB, Bernstein BM, da Silva BA. Loss of bone mineral density after antiretroviral therapy initiation, independent of antiretroviral regimen. J Acquir Immune Defic Syndr. 2009;51(5):554-61.

39. Grund B, Peng G, Gilbert CL, Hoy JF, Isaksson RL, Shlay JC, et al. Continuous antiretroviral therapy decreases bone mineral density. AIDS. 2009;23(12):1519-29.

40. Martínez E, Arranz JA, Podzamczer D, Loncá M, Sanz J, Barragán $\mathrm{P}$, et al; BICOMBO Study Team. A simplification trial switching from nucleoside reverse transcriptase inhibitors to once-daily fixed-dose abacavir/lamivudine or tenofovir/emtricitabine in HIV-1- 
infected patients with virological suppression. J Acquir Immune Defic Syndr. 2009;51(3):290-7.

41. Madeddu G, Spanu A, Chessa F, Calia GM, Lovigu C, Mannazzu M, et al. Serum leptin and bone metabolism in HIV patients treated with highly active antiretroviral therapy. $\mathrm{O} \mathrm{J}$ Nucl Med Mol Imaging. 2009;53(3):290-301.

42. Jacobson DL, Spiegelman D, Knox TK, Wilson IB. Evolution and predictors of change in total bone mineral density over time in HIV-infected men and women in the nutrition for healthy living study. J Acquir Immune Defic Syndr. 2008;49(3):298-308.

43. McComsey GA, Lo ReV 3rd, O'Riordan M, Walker UA, Lebrecht D, Baron $E$, et al. Effect of reducing the dose of stavudine on body composition, bone density and markers of mitochondrial toxicity in HIV-infected subjects: a randomized controlled study. Clin Infect Dis. 2008;46(8):1290-6.

44. Jones S, Restrepo D, Kasowitz A, Korenstein D, Wallenstein S, Schneider $A$, et al. Risk factors for decreased bone density and effects of HIV on bone in the elderly. Osteoporos Int. 2008;19(7):913-8.

45. Cassetti I, Madruga JV, Suleiman JM, Etzel A, Zhong L, Cheng AK, Enejosa J; Study 903E Team. The safety and efficacy of tenofovir DF in combination with lamivudine and efavirenz through 6 years in antiretroviral-naïve HIV-1-infected patients. HIV Clin Trials. 2007;8(3):164-72.

46. Calza L, Tampellini L, Farneti B, Borderi M, Chiara Pajno M, Biagetti $\mathrm{C}$, et al. Bone mass loss in patients with human immunodeficiency virus type 1 infection: Association with male sex and protease inhibitor therapy. Infec Dis Clin Pract. 2007;15(3):160-6.

47. Wiercinska-Drapalo A, Jaroszewicz J, Tarasow E, Siergiejczyk L, Prokopowicz D. The possible association between serum cholesterol concentration and decreased bone mineral density as well as intravertebral marrow fat in HIV-1 infected patients. Infection. 2007;35(1):46-8.

48. Bongiovanni M, Fausto A, Cicconi P, Aliprandi A, Cornalba G, Bini $T$, et al. Non-nucleoside-reverse-transcriptase-inhibitor-based HAART and osteoporosis in HIV-infected subjects. J Antimicrob Chemother. 2006;58(2):485-6.

49. Fausto A, Bongiovanni M, Cicconi P, Menicagli L, Ligabò EV, Melzi S, et al. Potential predictive factors of osteoporosis in HIV-positive subjects. Bone. 2006;38(6):893-7.
50. Bongiovanni M, Fausto A, Cicconi P, Menicagli L, Melzi S, Ligabo VE, et al. Osteoporosis in HIV-infected subjects: a combined effect of highly active antiretroviral therapy and HIV itself? J Acquir Immune Defic Syndr. 2005;40(4):503-4.

51. Martin K, Lawson-Ayayi S, Miremont-Salamé G, Blaizeau MJ, Balestre $E$, Lacoste D, et al; Groupe d'Epidémiologie Clinique du SIDA en Aquitaine. Symptomatic bone disorders in HIV-infected patients: incidence in the Aquitaine cohort (1999-2002). HIV Med. 2004;5(6):421-6.

52. Landonio $S$, Quirino T, Bonfanti $P$, Gabris A, Boccassini L, Gulisano $\mathrm{C}$, et al. Osteopenia and osteoporosis in HIV+ patients, untreated or receiving HAART. Biomed Pharmacother. 2004;58(9):505-8.

53. Tebas P, Yarasheski K, Henry K, Claxton S, Kane E, Bordenave B, et al. Evaluation of the virological and metabolic effects of switching protease inhibitor combination antiretroviral therapy to nevirapine-based therapy for the treatment of HIV infection. AIDS Res Hum Retroviruses. 2004;20(6):589-94.

54. Cirelli A, Cirelli G, Balsamo G, Masciangelo R, Stasolla A, Marini M. Body habitus changes, metabolic abnormalities, osteopenia and cardiovascular risk in patients treated for human immunodeficiency virus infection. Ann Ital Med Int. 2003;18(4):238-45.

55. Loiseau-Pérès $S$, Delaunay $C$, Poupon $S$, Lespessailles E, Ballouche $\mathrm{N}$, Arsac $\mathrm{P}$, et al. Osteopenia in patients infected by the human immunodeficiency virus. A case control study. Joint Bone Spine. 2002;69(5):482-5.

56. McDermott AY, Shevitz A, Knox T, Roubenoff R, Kehayias J, Gorbach $\mathrm{S}$. Effect of highly active antiretroviral therapy on fat, lean, and bone mass in HIV-seropositive men and women. Am J Clin Nutr. 2001;74(5):679-86.

57. Moore AL, Vashisht A, Sabin CA, Mocroft A, Madge S, Phillips AN, et al. Reduced bone mineral density in HIV-positive individuals. AIDS. 2001;15(13):1731-3.

58. Lawal A, Engelson ES, Wang J, Heymsfield SB, Kotler DP. Equivalent osteopenia in HIV-infected individuals studied before and during the era of highly active antiretroviral therapy. AIDS. 2001;15(2):278-80.

59. Triant VA, Brown TT, Lee H, Grinspoon SK. Fracture prevalence among human immunodeficiency virus (HIV)-infected versus non-HIV-infected patients in a large U.S. healthcare system. J Clin Endocrinol Metab. 2008;93(9):3494-504. 